\title{
O CONCEITO DE TERCEIRO NO PROCESSO CIVIL
}

\author{
André de Albuquerque Cavalcanti Abbud \\ Mestrando em Direito Processual Civil na Faculdade de \\ Direito da Universidade de São Paulo.
}

Resumo:

A claboração de uma definição de terceiro deve pautar-se por critérios de utilidade, buscando torná-la a mais operativa no âmbito do processo civil. O plano de referência do conceito que atende a tais critérios é apontado pelos usos mais comuns atribuidos ao termo, pela doutrina e pela lei, os quais são confirmados pela prática processual. A partir dessa realidade, chega-se à definição de terceiro como aquele sujeito que não é parte em determinado processo e, portanto, não pode ficar subordinado à autoridade da coisa julgada lá formada.

\begin{abstract}
:
The creation of a definition of "third party" in civil procedural law must follow parameters of usefulness. in order to provide practical use to the expression. The scope that fulfils such criteria is pointed by the most common ways in which the term "third party" is used by law and by books of authority. Those ways are confirmed by the procedural practice. Based on that, "third party" is defined as the person who does not take part in a lawsuit, and, therefore, cannot be submitted to the authority of res judicata.
\end{abstract}

Unitermos: conceito de terceiro; partes e terceiros; coisa julgada.

Keywords: "third party"; "res judicata"; procedural practice.

Sumário: 1 - introdução: por que e para que uma definição de terceiro. 2 - âmbito relevante do conceito de terceiro. em direito processual civil. 3 - premissa: eficácia da sentença $X$ autoridade da coisa julgada. 4 - o terceiro na prática processual. 4.1 intervenção de terceiros. 4.2 - obrigações solidárias e regressivas. 4.3 - sucessão processual. 4.4 - substituição processual. 4.4.1 -- tutela individual. 4.4.2 - tutela coletiva. 4.5 - ações de estado. 5 - conclusão. 6 - bibliografia. 
1. Introdução: por que e para que uma definição de terceiro.

O que significa dizer que alguém é terceiro, em direito processual civil? Essa pergunta tem atormentado muitos, ontem e hoje, no Brasil e no exterior, dividindo as opiniões da doutrina.'

Sua formulação, na verdade, pressupõe uma outra questão, que deve anteceder àquela em qualquer investigação científica no campo do direito que se pretenda afinada com as orientações metodológicas contemporâneas: é relevante procurar traçar uma definição de terceiro em processo civil? Sim, porque se encontra hoje definitivamente ultrapassada a visão que centrava na perquirição de uma natureza jurídica dos institutos a pauta de atividades do cientista do direito. Estava ela ligada ao ideário do Estado Liberal, repressor e garantista, preocupado antes de tudo com a sistematização, exegese e aplicação estabilizada da ordem juridica, tarefa a que dava cabo punindo comportamentos transgressores das normas. Já no início do século passado, tal concepção cedeu lugar à do Estado de caráter social que, a despeito de ter assumido na última década caráter mais propriamente regulador, desempenha o papel de incentivador e balizador de comportamentos por meio da instituição de sanções premiais, voltadas à consecução de fins pré-estabelecidos, como as promoções social e econômica. ${ }^{2}$ Essa evolução política, que não deixou de marcar a transformação da ciência jurídica, representou nesta a passagem de uma concepção estruturalista para outra, de ordem funcionalista. ${ }^{3}$ As preocupações do jurista devem, assim, voltar-se hoje não mais à investigação auto-centrada de naturezas e definições, desvinculadas de um propósito definido, mas sim ao estudo, criação e aprimoramento finalístico dos institutos, com os olhos postos sobre os objetivos que sua existência ou advento

I. ALLORIO, La cosa giudicata rispetto ai terzi, passim; LIEBMAN, Mamuale di diritto procesuale civile, n. 41 ; DINAMARCO, Litisconsórcio, p. 26-28, Instituiçóes de direito processual civil, p. 369-370, e Coisa julgada e intervenção de terceiros, p. 16-18; MONIZ DE ARAGÃo, Observações sobre os limites subjetivos da coisa julgada, p. 10 ss.; BAPTISTA DA SIlva, Curso de processo civil, p. 235-241; GRECO FILHO, Da intervençâo de terceiros, p. 22-38; SCARPINELLA BUENO, Partes e terceiras no processo civil. p. $2-10$.

2. Mais recentemente. o Estado "passa a atuar como regulador das atividades privatizadas, como balizador da concorrência, como estimulador da oferta de serviços essenciais num ambiente competitivo. como garantidor dos direitos do consumidor e como criador de oportunidades de negócios para a iniciativa privada e de investimento para o desenvolvimento tecnolúgico" (FАRIA, Regulação, direito edemacracia, p. 8). Como se vê. tal como o Estado social o regulador também orienta sua atuação finalisticamente.

3. BOBBIO, Dalla strutura alla funzione, pussim; FERRAZ JLNIOR, O pensanento juridico de Norbento Bobbio. p. 12-16; CAFFÉ Alves, Apresentação, p. 18-19. 
procuraram alcançar. ${ }^{4}$ Eis a razão pela qual é pertinente tratar, preliminarmente, da questão da importância funcional que orienta a tentativa de elaborar uma definição de terceiro, para fins processuais civis.

O tipo mais familiar de definição, segundo indica Hart, ${ }^{5}$ é aquele que procura traçar as linhas do termo por meio de distinções e aproximações entre uma espécie de coisa e outra(s), expressadas em palavras distintas (per genus et differentiam). Ela propicia a tradução do termo para outras palavras de uso relativamente assente, ao mesmo tempo em que identifica o objeto definido apontando nele tanto os elementos que o inserem em uma familia mais ampla de coisas, quanto os que o diferenciam de outras da mesma família. Pode-se dizer que as tentativas de se conceituar quem seja terceiro, no processo civil, valem-se freqüentemente dessa forma de definição. Terceiro seria, por contraposição, aquele que não é parte no processo. ${ }^{6}$

Tomada nessa acepção, a definição almeja constituir-se em uma regra com base na qual possa ser testada a correção do uso da palavra. ${ }^{7} \mathrm{O}$ problema de se saber ser ou não possível elaborar uma noção de terceiro nesse sentido, dotada de limites tão precisos, deverá ser aqui enfrentado (infra n. 5).

Por ora, entretanto, importa notar que a definição se constrói por referência a uma realidade, um objeto ou conjunto de objetos que se pretende elucidar. No campo do direito. mais exatamente, essa realidade não é um dado apriorístico, mas é estipulada pelo intérprete, que cria seu objeto teórico, de acordo com os propósitos que o movem na busca da definição. Isso porque, nessa tarefa, o jurista é pautado pela idéia de utilidade. Não o guiam apenas objetivos informativos, mas também e principalmente diretivos; ele não apenas descreve como algo é entendido, mas também propõe como deve sê-lo, em determinado texto ou contexto, segundo critérios de

4. FERRAZ JÚNIOR, O pensamento juridico de Norberlo Bobbio, p. 15-16.

5. The concept of law, p. 18-19.

6. CALAMANDREI, Istituzioni di diritlo processuale civile, p. 243; LIEBMAN, Manuale di diritto processuale civile, p. 90; FREDERICO MARQLES. Instituições de direito processual civil, v. 2, p. 92; MONZ DE ARAGÃO, Observações sobre os limites subjetivos da coisa julgada, p. 11; DINAMARCO, Litisconsórcio, p. 26, e Intervenção de terceiros, p. 18; CARNEIRO, Intenvenção de terceiros, p. 49; PORTO, Comentários ao código de processo civil, p. 211; PINTO, O terceiro recorrente, p. 27-28. Mesmo Rocoo, que não segue idêntica linha, reconhece gozar ela de aceitação predominante (Trattato di diritto processuale civile, v. 2, p. 336, nota 2).

7. HAR'1, The concept of law, p. 21. 
funcionalidade. ${ }^{8}$ Em outras palavras, a definição jurídica scrá tanto mais valiosa quanto mais útil se mostrar para descrever e orientar a compreensão de uma realidade, tal como estipulada pelo intérprete. Daí chamarem-se as definições jurídicas de estipulativas," ou "redefinições" in

Ao se tentar elaborar uma definição de terceiro, portanto, deve ter-se bem presente qual a realidade a que se pretende referir. A variação desse objeto estipulado altera na mesma medida a idéia que se tenha do termo terceiro. Uma fixação dessa ordem, portanto, traz no mínimo a grande vantagem de dissolver ambigüidades no uso do termo, ${ }^{11}$ causa já em si de confusão no trato da matéria. ${ }^{12}$

2. Âmbito relevante do conceito de terceiro, em Direito Processual Civil.

A questão da importância de uma definição de terceiro liga-se, assim, à identificação (estipulação) do âmbito da realidade para cuja referência a noção de tercciro mostra-se relevante. Um primeiro indício, ainda genérico e turvo, do fenômeno designado pelo termo vem do léxico. Terceiro é o outro. ${ }^{13}$ Nesse sentido, terceiro seria aquele que não integra determinado objeto de análise, o que está fora dele.

É possível dizer que com tal contorno a noção de terceiro sempre foi utilizada no campo do direito. Tomada uma relação jurídica, grosso modo, como vínculo entre dois ou mais sujeitos regulado pelo sistema normativo. ${ }^{14}$ terceiro designa

8. FERRAz JÚNIOR, Introdução ao estudo do direito - decisão, técnica, dominação, p. 39. "Neste sentido se diz também que a ciência jurídica não apenas informa, mas conforma o fenômeno que wurka. faz parte dele. A posse ć não apenas o que é socialmente, mas também como é interpretada pela doutrina juridica"

9. WARA I, O direito e sua linguagem, p. 57; LOPF, As palavras e a lei, p. 27; FERRA7JÚNHOR, ob. cit. p. 36.

10. FERRAZ JÚNIOR, ob. cit., p. 37 e 39, in fine. $57)$.

11. Fssa é mesmo uma das funções da definição estipulativa (W ARA1, O direiro e sua lingruagem, p.

12. Não é infreqüente o uso, por um mesmo autor. do tcrmo terceiro em sentidos não univocos. A imprecisão mais comum é a que caminha de uma noção cstritamente processual para outra orientada pela relação de direito material. Assim. p. ex., CALAMANDREI, Istituzioni di diritto processuale civile, p. 243; PINTO. O terceiro recorrente. p. 27 e 36; CARNEIRO, Intervenção de terceiros, p. 49 e 50.

13. Novo dicionário aurélio. Rio de Janeiro. Nova fronteira, 1975. p. 1.379.

14. LUMIA, Lineamenti di teoria e ideologia del diritto, p. 99; MACHADO, Introdução ao direito e ao discurso legitimador. p. 86; REALE, Lições preliminares de direito. p. 212. 
aquele alheio a esse vínculo. ${ }^{15} \mathrm{O}$ âmbito de referência do termo é, assim, delimitado por exclusão: terceiro é aquele que não é parte de determinada relação jurídica, um não-parte, na expressão de Carnelutti. ${ }^{16}$

$\mathrm{Na}$ esfera do direito processual, como visto, mesmo uso é freqüentemente conferido ao termo. Terceiros são os sujeitos situados fora da relação jurídica processual. ${ }^{17}$ Essa idéia atingida por contraponto à noção de parte explica o porquê de a generalidade da processualistica tradicional preocupar-se não tanto em definir quem seja terceiro. mas sim em quem sejam as partes. ${ }^{18}$

Essa preocupação, em verdade, traz em seu bojo outra, ligada à afirmação da autonomia da relação jurídica processual, por seus pressupostos, sujeitos e objeto, quando comparada ao liame de direito material - o que define a própria postura metodológica dos que o fazem em prol da autonomia da ciência processual. ${ }^{19}$ No trato do tema, a doutrina clássica apressa-se em dizer que partes. para fins específicos de direito processual civil, são "os sujeitos dos direitos e dos deveres processuais". ${ }^{20}$ isto é, os sujeitos "de la relación juridica procesal" ${ }^{21}$ Com isso, pretendem deixar claro que "il concetto di parte è squisitamente formale e processuale, e quando si tratta di definirlo le norme sostunziali non hanno alcun rilievo" 22

De fato. há toda uma realidade de fenômenos, inseridos no contexto processual. à qual se relaciona uma idéia própria e exclusiva de partes - e portanto de terceiros. Para o fím de solucionar questões atinentes aos efeitos da litispendência. à coisa julgada, ao custo do processo, à intervenção de terceiros, ao litisconsórcio, ao

15. CARNELL! I [1, Teoria generale del diritto, p. 106.

I o. Teoria generale del diritlo, p. 107.

17. LiEBMAN, Manuale di diritto processuale civile, p. 90.

18. GOLDSCHMIDT, Zivilprozessrecht, p. 165, 328 ss. e 368 ss.: W ACH, Handbuch des deutschen zivilprozessrechts, t. 1, p. 281-282, 407 ss.; LENT, Zivilprozessrecht, p. 60 ss.; ROSENBERG, Lehrbuch des deutschen zivilprozessrechts, p. 211 ss. e 264; CHIOVENDA, Istituzioni di diritto processuale civile.v. 2, p. 233 ss.; CARNELUTTI, Istituzioni del nuovo processo civile italiano, v. 1, p. 220 ss.; CALAMANDREI, Istituzioni di diritto processuale civile, v. 2, p. 229 ss..

19. Dinamarco, A instrumentalidade do processo, p. 18-19.

20. GOLDSCHMIDT, Zivilprozessrecht, p. 165.

2I. WAC11, Handbuch des deutschen zivilprozessrechts, 1. I, p. 281; ROSENBERG, Lehrbuch des deutschen zivilprozessrechts. p. 212; C.ILAMANDREI, Istituzioni di diritto processuale civile, p. 229-230.

22. LENT, Livilprozessrucht, p. 62. No mesmo sentido, GOLDSCHMIDT, Zivilprozessrecht, p. 165; CHIOVENDA, Istituzioni di diritto processuali civile, v. 2, p. 234-235. 
impedimento e à suspeição do juiz, aos deveres, ônus e faculdades processuais, é decisivo e necessário um conceito de parte elaborado independentemente de qualquer ligação com o direito substancial. ${ }^{23}$

Por essa razão, procurar definir quem sejam partes e terceiros no âmbito do processo civil, pretendendo referir-se àqueles temas - nos quais o uso desses termos faz-se útil -, buscando os critérios para tanto no direito material, é tarefa destinada ao insucesso. Afinal, ainda que um sujeito da relação processual não seja parte na relação juridica substantiva deduzida em juizo, ele permanece titular de faculdades, deveres e ônus dentro do processo, razão por que é parte em sentido processual. Não será talvez parte legítima, mas parte o é. ${ }^{24}$ Em contraposição, o terceiro em relação ao processo, para todos os fins como tal deve ser considerado, ainda que seja parte no liame de direito material. Eis a razão por que, ao contrário do que entendeu Calamandrei, ${ }^{25}$ não se pode negar utilidade, a fim de evitar confusões, à divisão proposta por Carnelutti ${ }^{20}$ entre as noções de parte em sentido processual e parte em sentido material.

O ordenamento processual parece apontar com freqüência para esse uso do termo terceiro, significando aquele que não é parte no processo. Assim age, por exemplo, quando insere no capítulo atinente à "intervenção de terceiros" as situações em que sujeito estranho à relação processual a ela se integra (CPC, arts. 56-80); quando legitima à propositura da ação rescisória, lado a lado, "quem foi parte no processo" e o "terceiro juridicamente interessado" (art. 487, incs. I e II), fazendo o mesmo quanto à interposição de recursos (art. 499); quando estabelece estarem sujeitos à execução os bens do devedor (parte), "quando em poder de terceiros" (art. 591, inc. III); quando

23. GOLDSCHMIDT, Zivilprozessrecht, p. 165; CHIOVENDA, Istituzioni di diritto processuale civile, v. 2, p. 233-234.

24. Diz LHNT: "può darsi che egli non sia affatto creditore, o che il convenuto non sia la persona obbligata; ma ciò non ha alcuna importanza quando si tratla di individuare le parti: e l'uno e l'altro mantengono comunque tale qualifica; (...). Se anche i litigante non sono titolari del rapporto dedotto in iudizio, cio non ha alcuna importanza (...)" (Zivilprozessrecht, p. 62). E ROSENBERG: "este concepto del derecho procesal alemán (inico decisivo) es independiente de la estructura del derecho material y de la posición juridica extraprocesal de los interesudos. Porque no se es parte en el proceso civil como tinular de la relación juridica controvertida, sino actor es quien afirma el derecho (material): y demandado. aquel contra quien se lo hace valer. Para lu posición de parte procesal no tiene importancia si el actor es el poseedor del derecho y si el demandado es el verdadero obligado o afectado". (Lehrbuch des dentschen zivilprozessrechts, p. 211 ). No mesmo sentido, no Brasil. DINAMARCU. Instituições de direito processual civil, v. 2, p. 247-249.

25. Istituzioni di diritto processuale civile, v. 2, p. 230.

26. Istituzioni del nuovo processo civile italiano, v. 1, p. 221. 
concede a via dos "embargos de terceiro" àquele que. "não sendo parte no processo, tiver sofrido turbação ou esbulho na posse de seus bens" (art. 1.046); quando prescreve o dever de indenizar àquele "que pleitear de má-fé como autor, réu ou interveniente" na seção atinente à "responsabilidade das partes por dano processual" (CPC, art. 16) etc.

A identificação dos sujeitos alheios à relação juridica processual (terceiro como contraponto das partes no processo) constitui, assim, um primeiro corte da realidade para cuja referência faz-se útil o recurso ao conceito de terceiro. Dado fincar suas raizes no puro exame dos sujeitos do vínculo estabelecido diante do juiz, é possivel denominar essa perspectiva de endo-processual, ou técnico-processual.

Assim se faz para apartá-la de outro corte da realidade em que o conceito de terceiro mostra-se tão ou mais relevante, e que tem matrizes, para além de processuais. constitucionais. Afinal, liga-se aos chamados limites subjetivos da coisa julgada, instituto que já Liebman ${ }^{27}$ afirmava integrar a ordem constitucional, o que é endossado por nosso sistema (CF, art. $5^{\circ}$, inc. XXXVI). Nessa segunda perspectiva, terceiro é, tradicionalmente e com freqüência, apontado como o sujeito que não pode ficar submetido à autoridade da coisa julgada. ${ }^{28}$

Essa acepção do vocábulo tem origem remota no Direito Romano, ${ }^{29} \mathrm{de}$ onde lançou-se para integrar-se definitivamente à tradição jurídica luso-brasileira. ${ }^{30}$ Historicamente, guarda independência daquela primeira perspectiva, uma vez que,

27. Efficacia ed autorità della sentenza, p. 55.

28. GOLDSCHMIDT, Zivilprozessrecht, p. 328; LENT, Zivilprozessrecht, p. 251-252; ROSENBERG, Lehrbuch des deutschen zivilprozessrechts, p. 479-480: CHIOVENDA, Istituzioni di diritto processuale civile, v. I. p. 414; LIEBMAN, Efficacia ed autorità della sentenza, esp. p. 56 e 80 ss.; MONTELEONE, I limiti soggettivi del giudicato civile, esp. p. 9 ss. e 164 ss.; COUTURE, Fundconentas del derecho procesal civil, p. 422; FREDERICO MARQUES, Instituições de direito processual civil, v. 4, p. 342-343; MONIZ DE ARAGÄO, Observaçōes sobre os limites subjetivos da coisa julgada, esp. p. 22; CNTRA, Comemínias co código de processo civil, v. 4, p. 318 ; DinAMARCO, Intervenção de terceiros, p. 15; BAPTITADASU.va, Curso de processo civil, v. I, p. 493-494.

29. "Saepe constitutum est res inter alios iudicatas uliis non praeiudicare" "Res inter alios indicutas nullum aliis praeiudicium facere" (D. 42, 1, 63 e 44, 2, 1, apud ORFSTANO, L' oppello civile in diritlo romano, p. 322-323).

30. "Em Portugal e no Brasil sempre foi acatado o principio nela consagrado (regra da res inter alias iudicata), que figurou jả nas Ordenações Afonsinas. Foi incluido na Consolidação Ribas (art. 501), e, embora não haja figurado nos Códigos estaduais. nem no Código de Processo (ivil de 1939, jamais deixou de ser respeitado. Sua inserção neste Código retoma o fio de antiga e salutar tradição jurídica" (MONIZDE ARAGÃO, Observações sobre os limites subjetivos da coisa julgada, p. 8). 
como se sabe, até o século XIX a visão sincrética do ordenamento jurídico não dissociava a ação do direito subjetivo, contaminada que estava pela noção da actio romana. ${ }^{31}$ Dessa forma, não se concebia que partes no processo pudessem ser sujeitos dilerentes das partes em sentido material, razão pela qual a afirmação de que terceiros não podiam se submeter à res iudicata não partia exatamente de sua concepção como sujeitos externos apenas à rélação processual.

Essa segunda realidade deriva também sua matriz constitucional do princípio do contraditório ( $\mathrm{CF}$, art. $5^{\circ}$ inc. LV). De fato, se a coisa julgada material incide somente sobre o resultado de processo desenvolvido sob a égide do contraditório entre as partes, ${ }^{32}$ seria absolutamente ilegítimo pretender estendê-la a quem não teve a oportunidade de contribuir para a formação do provimento, formulando alegações em seu favor, requerendo e produzindo provas, reagindo aos atos que the fossem desfavoráveis etc. ${ }^{33} \mathrm{~A}$ um processo civil orientado em bases democráticas, instituto de primeira grandeza do Estado de direito, repugnaria a produção imutável de efeitos concretos sobre a esfera de direitos de um sujeito, sem que lhe tivesse sido conferida a oportunidade de defender-se em juízo segundo os ditames legais. É exatamente a possibilidade de fazer valer suas razões diante do juiz que justifica a imposição às partes do dever de conformar-se com o resultado do processo, obrigação que resulta da incidência da coisa julgada. ${ }^{34}$ Fm outras palavras, é do exercício pleno do contraditório que o procedimento retira sua legitimidade, criando condições para a imunização da decisão final contra eventuais desapontamentos das partes. ${ }^{35}$ Daí por que a extensão da

31. Dinamarco, A instrumentalidade do processo, p. 18.

32. Segundo W ATANABL, somente ao "provimento que se assente em cognição plena exauriente, vale dizer, em procedimento plenário quanto à extensão do debate das partes e da cognição do juiz, c completo quanto à profundidade dessa cogniçào", (...) "o Estado confere a autoridade de coisa julgada" (Da cognição no processo civil, p. 113-114).

33. MONTELEONE, I limiti soggertivi del giudicado civile, p. 165. Sobre as atividades mencionadas como parte do conteúdo atual do princípio do contraditório, cf. DINAMARCO. Oprincipio do contractiório e suu dupla destinação, p. 124 ss e OLIVEIRA, Garantia do contraditório. p. I36 ss.

34. LIEBMAN, Efficacia ed autorità della sentenza, p. 56.

35. "A função legitimadora do procedimento nāo está em se produzir consenso entre as partes, mas em tornar inevitáveis e prováveis decepções em decepções difusas: apesar de descontentes, as partes aceitam a decisão" (FERRAZ JúNIOR. Apresentação, p. 4). 
coisa julgada a terceiros afrontaria ainda as garantias constitucionais da ampla defesa, do devido processo legal e do acesso à justiça ${ }^{36}$ (CF, art. $5^{\circ}$, incs. LV, LIV e XXXV). ${ }^{37}$

$O$ ordenamento processual também aponta para esse significado do termo, ao prescrever que "a sentença faz coisa julgada às partes entre as quais é dada, não beneficiando nem prejudicando terceiros" (CPC, art. 472), em disposição scmelhante à que consta dos direitos italiano (CC, art. 2.909) e alemão $(\$ 325, \mathrm{I}) .^{38}$

Têm-se, assim, os dois cortes da realidade para cuja referência o conceito de terceiro parece ser usado com maior freqüència. Em primeiro lugar, lança-se mão do termo para designar o sujeito que não integra a relação jurídica processual. Em scgundo, fala-se em terceiro como aquele que não pode fícar subordinado à coisa julgada material.

Como visto, ainda que se possa chugar à conclusão de que tais realidades estão interligadas (aquele que não foi parte do processo não pode se submeter à autoridade da coisa julgada), isso não quer dizer que não sejam fenômenos diferentes, um de ordem estritamente técnico-processual (a ausência da relação processual), outro de natureza constitucional (a impossibilidade de se impor os resultados definitivos do processo), de origens e fundamentos diversos.

Dado que ambas essas realidades são as mais recorrentes no trato do termo, em doutrina e na lei, faz-se então pertinente empreender a busca por uma definição precisa de terceiro a partir delas, já que é por referência a elas qui o conceito sc mostra mais útil, em direito processual.

Posto isso, é preciso verificar se a prática do processo confirma esses usos do termo, e se daí é possivel extrair uma única definição de terceiro. Para tanto, scrão passados em revista os principais institutos do direito positivo em que se opera o conceito, de onde se extrairá ao final uma conclusão a respeito de tais questões, segundo o método indutivo.

36. Nas palavras de MONIZ DE ARAGÃo, "se alguma relação juridica for atingida pela autoridade da coisa julgada surgida inter alios, isto é, em processo para o qual o titular não fora oportunamente citado (notifícado, intimado), seu direito individual terá sofrido uma lesão, sem haver sido apreciado pelo Poder Judiciário" (Observaçōes sobre os limiles subjetivos da coisa julgada, p. 22).

37. TALAMINI, Partes, terceiros e coisa julgada (os limites subjetivos da coisa julgada), p. 202-203.

38. O Código parece também se referir a essa concepção do vocábulo terceiro ao equiparar a tal o sujeito que, "posto figure no processo, defende bens que. pelo titulo de sua aquisiçào ou pela qualidade em que os possuir, não podem ser atingidos pela apreensão judicial" (art. 1.046, \$ $2^{\circ}$ ), disposição à qual está insita a idéia de terceiro como aquele que não pode ser prejudicado pelos resultados do processo. 
Antes, porém, tratar-se-á do que se entende aqui exatamente por coisa julgada e sua relação com a sentença, dada a importância de que o tema se reveste para os fins do presente trabalho.

3. Premissa: eficácia da sentença $X$ autoridade da coisa julgada.

Uma análise exaustiva e completa das diversas correntes sobre a coisa julgada que se formaram ao longo do desenvolvimento da ciência processual foge aos estritos limites deste trabalho. Ele não prescinde, no entanto, de uma rápida abordagem sobre o tema, a fim de que se tenha firme a posição aqui adotada sobre questão diretamente relacionada com o conceito de terceiro, segundo o quadro acima delineado.

A concepção mais tradicional sobre a coisa julgada insere-a dentre um dos efeitos da sentença. Na doutrina alemã, mais especificamente, ela seria o próprio efeito declaratório do decisum, ou a eficácia do elemento declaratório nele contido. ${ }^{39}$ Tal concepção foi seguida, dentre nós, por Pontes de Miranda ${ }^{40}$ e Celso Neves. ${ }^{41}$

Apesar da notória influência que os processualistas alemães da época exerceram sobre o pensamento de Chiovenda, foi ele quem lançou as bases para a identificação da coisa julgada em termos diferentes dos então prevalecentes. E fê-lo exatamente ao tratar dos limites subjetivos da coisa julgada, afirmando que "a coisa julgada, como resultado da definição da relação processual, é obrigatória para os sujeitos desta"; "mas, (...) a sentença existe e vale com respeito a todos" 42 Aí estavam, assim, as raízes de uma distinção entre os efeitos produzidos pela coisa julgada e pela sentença.

Foi Liebman, no entanto, quem identificou com precisão a diferença ontológica existente entre a efícácia da sentença e a coisa julgada - como reconhece Fazzalari, que a adota. ${ }^{43}$ Segundo a visão defendida na clássica monografia daquele autor sobre o tema, a doutrina tradicional incorreria em "erro lógico" ao enquadrar a

39. GOLDSCHMIDT, Zivilprozessrecht, p. 321 e 330: LENT, Zivilprozessrecht, p. 258; ROSENBERG, Lehrbuch des deutschen zivilprozessrechts. p. 442.

40. Comentários an código de processo civil. t. V. p. 157.

41. Coisa julgada civil, p. 502.

42. Istituzioni di diritto processuale civile. p. 414.

43. The judgment and the authority of res judicala, p. 246 ss.. 
coisa julgada dentre um dos efeitos da sentença, pois equipararia coisas heterogêneas sob 0 mesmo rótulo. ${ }^{44}$ Afinal, os efeitos da sentença produzir-sc-iam independentemente da coisa julgada, isto é, existiriam ainda que não se pudesse reputálos imutáveis e indiscutíveis. Dessa forma, ela não seria um dos efeitos da sentença, mas "qualquer coisa mais que se ajunta para aumentar-Ihes a estabilidade", sem alterarIhes a própria natureza. ${ }^{45}$

Além disso, a indissociação entre a coisa julgada e o efeito declaratório da sentença, propugnada pela doutrina alemã, produziria resultados inaceitáveis, consistentes em negar a autoridade da coisa julgada aos demais efeitos produzidos pelo decisum, constitutivo e condenatório - o que não se justificaria -, e negar autonomia ao efeito declaratório, absorvido que estava pela noção de coisa julgada. ${ }^{46}$

$O$ labor de Liebman distinguiu com clareza, assim, os efeitos produzidos pela sentença, como ato jurídico estatal, da autoridade a eles conferida pela coisa julgada, a qual consistiria em uma especial "qualidade dos efeitos da sentença" 47

Essa teoria sofreu pertinente crítica de Barbosa Moreira, a qual no entanto não se volta contra ela em toda sua essência; antes acaba por aperfeiçoá-la. $O$ professor carioca não nega a diferença entre os efeitos da sentença e a coisa julgada, tomada esta como qualidade que a eles adere; apenas rejeita a tese de que tal autoridade incidiria sobre os efeitos da sentença, e não, como seria mais apropriado falar, sobre o conteúdo desta, isto é, sobre a "norma jurídica concreta nela contida" Isso porque os efeitos da sentença podem deixar de existir ou alterar-se, como ocorre naturalmente com o efeito condenatório em função do pagamento ou da execução forçada, ou em razão de convenção das partes em sentido diverso (p. ex., relação jurídica cleclarada ou constituida na sentença), tratando-se de direitos disponíveis, sem que o comando sentencial deixe de estar acobertado pela coisa julgada. Ainda que scus efeitos possam extinguir-se ou modificar-se, o conteúdo da sentença permanece imune a eventuais ataques das partes ou subseqüentes apreciações judiciais. ${ }^{48}$

44. Efficacia ed autorità della sentenza, p. 18.

45. Ob. cit., p. $19-20$ e 37-40.

46. Ob. cit., p. 6 e 42 .

47. Ob. cit., p. 40. Cf. também, do mesmo autor, The notion of res judicata, p. 237.

48. Eficácia da sentença e autoridade da coisa julgada, p. 109 ss.. 
O reparo de Barbosa Moreira, como se vê, procede. Com efeito, parece mais adequado falar que a autoridade da coisa julgada incide sobre o comando contido no conteúdo da sentença, e não exatamente sobre os efeitos desta. De todo modo, para os fins do presente estudo, o importante é marcar a nítida diferença existente entre a eficácia da sentença e sua imunização produzida pela coisa julgada, contribuição de Liebman que se incorporou à doutrina processual brasileira. ${ }^{49}$

Tal distinção, de fato, é que permite o adequado equacionamento do problema da relação dos terceiros com a sentença e com a coisa julgada. Afinal, tomados os efeitos e a autoridade do decisum de forma indissociada, o reconhecimento de que terceiros são atingidos por aqueles levaria necessariamente à conclusão de que também estão sujeitos à coisa julgada. ${ }^{50}$ É o que faz Carnelutti, por exemplo. ${ }^{51}$

Diferentemente, a quem veja os finômenos da eficácia sentencial c de sua estabilização como ontologicamente diversos, é possível apreender a correta dimensão daquele enunciado de Chiovenda, no sentido de que "a coisa julgada, como resultado da defínição da rclação processual, é obrigatória para os sujeitos desta; (..) mas (...) a sentença existe e vale com respeito a todos" ${ }^{52}$ Como ato juridico de império emanado do poder estatal, em uma de suas manifestações que é a jurisdição, a sentença deve ser observada por todos, inclusive terceiros. ${ }^{53}$ Quer isso dizer que, via de regra, todos são afetados pelos efeitos da sentença até porque as relações jurídicas não existem isoladamente no plano da realidade. ${ }^{54}$ Entretanto, como visto, a ordem constitucional rejeita que aqueles que não participaram do processo fiquem vinculados à imutabilidade da coisa julgada lá produzida (CF, art. $5^{\circ}$, incs. XXXV, LIV e LV). Em

49. FREDERICO MARQUES, Instituições de direito processual civil, v. 4, p. 323; DINAMARCO, Instituições de direito processual civil, v. 3, esp. p. 303 ss.; CINTRA-GRNOVER-DINAMARCO, Teoria geral do processo, p. 306; MESQUiTa, A coisa julgada, p. 23; BA TISTA DA SILVA, Closo de processo civil, v. I. esp. p. 493 ss.: PORTO, Comentários ao código de processo civil, v. 6, p. 212-213.

50. LIEBMAN, Efficacia ed auturità della sentenza, p. 79.

51. Efficacia dirella e efficacia riflessa della cosa giudicata, passim.

52. Istituzioni di diritto processuale civile. p. 414.

53. LIEBMAN, ob. cit., p. 138 ss., c La cosa giudicala nelle questioni di stato, p. 201; MESQUTTA, A coisa julgada no código do consumidor, p. 24-25.

54. LIEBMAN, ob. cit., p. 80. 
caso de prejuízo à sua esfera de direitos, podem eles opor-se àqueles efeitos pela via jurisdicional. $^{55}$

À luz dessas considerações, vejamos então como se dão, na prática do processo, as relações entre a sentença, seus efeitos, a coisa julgada e os assim chamados terceiros, a fím de verificar se é possível extrair uma definição única do que sejam estes.

4. O terceiro na prática processual.

4.1. Intervenção de terceiros.

Da constatação de que a complexidade social torna as relações juridicas entre os sujeitos muitas vezes inter-relacionadas, sob diversas formas e graus, depreende-se que também sob muitas formas os efeitos produzidos pela sentença atingem aqueles que não foram partes em determinado processo. As classificações mais tradicionais dividem tais sujeitos, basicamente, em duas categorias distintas: $\left(1^{\circ}\right)$ os que são totalmente, ou apenas sob o ponto de vista jurídico, indiferentes ao resultado do processo, dado serem titulares de relações completamente estranhas ao objeto do processo, ou com ele compatíveis; e $\left(2^{\circ}\right)$ os que são titulares de relações jurídicas incompativeis com a sentença, e portanto juridicamente interessados em relação ao objuto do processo. ${ }^{56}$

Do plexo multiforme das variadas relações assim estabelecidas entre o conteúdo da sentença e as esferas juridicas de sujeitos estranhos ao processo, surgem as situações em que, em razão de sua legitimidade e interesse, é dado a estes intervir na relação processual, a fím de participar da formação do pronunciamento jurisdicional com vistas a impedir que ele cause prejuizo à sua órbita de direitos, ou afastar provimento já proferido contra seus interesses. Para tanto, o ordenamento lhes franqueia as vias da assistência e da oposição (CPC, arts. 50 a 61), assim como do recurso de terceiro prejudicado (CPC, art. 499). Desse mesmo quadro emanam outras

55. Talamin,, Partes, terceiros e coisa julgada. p. 204.

56. ChIOvenda, Istituzioni di diritlo processuale civile. p. 421-422: LIEBMAN, Efficacia ed catorità della sentenza. p. 92; DinamarCo, Coisa julgada e intervenção de terceiros, p. 19; MONZDEARAGÃo, Observações sobre os limites subjetivos da coisa julgadi, p. 9; BAPTISTA DA SILVA, Curso de processo civil, p. 500. 
situações, em que às próprias partes convém tomar a iniciativa de integrar à relação processual sujeito a ela estranho, com o objetivo de extrair do julgamento a maior utilidade possivel. Instrumentos disso são a denunciação da lide, o chamamento ao processo e a nomeação à autoria (CPC, arts. 62 a 80$).{ }^{57}$

O Código de Processo Civil reúne quase todas ${ }^{58}$ essas modalidades de intervenção no processo de um sujeito estranho a ele sob o título de "intervenção de terceiros" Com seu ingresso, seja qual for a forma processual que o instrumentalize, tal sujeito passa a deter faculdades, deveres e ônus dentro da relação processual, ainda que limitadas $\cdots$ no caso da assistência. ${ }^{59}$ Adquire, assim, a condição de parte do processo. ${ }^{60}$

Em todos os casos, as chamadas intervenções de terceiros ampliam os efeitos da sentença a ser proferida no processo, que atingirão também os sujeitos intervenientes. Seja alargando o objeto do processo (pedido, pretensão nele deduzida), seja cleixando-o intacto, a intervenção tem o efeito de fazer com que as novas partes fiquem diretamente sujeitas aos resultados do processo e, mais que isso, vinculadas à autoridade da coisa julgada nele produzida. Afinal, é precisamente essa a utilidade das intervenções, quer coercitivas, quer voluntárias. ${ }^{61}$ Tendo o interveniente, na condição de parte, contribuído ativamente para a formação do provimento final. nenhuma razão constitucional há para negar-lhe a imposição da coisa julgada material.

No caso da assistência, mais especificamente, a vinculação do interveniente ao resultado do processo se dá sob a forma do "efeito" ou da "eficácia da intervenção" (Interventionswirkung). Da proibição, imposta pela lei, de que o assistente discuta a "justiça da decisão" proferida no processo em que interveio (CPC. art. 55).

57. Dinamarco, Coisa julgada e intervenção de terceiros, p. 20-21; GreCo FllHO, Da interunção de terceiros, p. 38-39; Amaral SAntos, Primeiras linhas de dircilo processual civil, p. 16-17.

58. Exceção feita à assistência.

59. Apesar da condição de coadjuvante a uma das partes no processo, não deixa de ser parte o assistente, "o qual não deduz demanda alguma e em face do qual demanda alguma é deduzida, mas é titular dos poderes, faculdades, deveres etc. que compõem a relação juridica processual" (DINAMARCO, Coisa julgada e intervenção de terceiros, p. 17). Dai chamarem-no alguns de "parte acessória", para distingui-lo da "parte principal", a qucm assiste (RUSFNBERG, Lehrbuch des deutschen zivilprozessrechts, p. 264). Mesmo quem nega ao assistente a condição de parte reconhece poder ele realizar, em regra, todos os atos processuais, inclusive postular e produzir provas, interpor recursos etc. (GOLDSCHMIDT, Zivilprozessrecht, p. 369).

60. CARNEIRO, Intervenção de terceiros. p. 49: DINAMARCO, Instituições de direito processual civil, p. 366.

61. DINAMARCO, Coisa julgada e intervenção de terceiros, p. 25. 
extrai-se ficarem indiscutiveis e imutáveis, perante ele, não apenas o dispositivo, mas também os fundamentos jurídicos da sentença. ${ }^{62} \mathrm{Se}$, por esse lado, a "eficácia da intervenção" assistencial é mais severa que a autoridade da coisa julgada, por outro é mais branda, haja vista que o assistente se subtrai dessa vinculação se demonstrar que não teve plenas condições de fazer valer suas razões no processo em função da conduta do assistido ou do estado em que recebera a causa (exceptio male gesti processus CPC, art. 55, incs. I e II). ${ }^{63}$

\subsection{Obrigações solidárias e regressivas.}

A lei material prevê inúmeras situações em que, havendo vários titulares do mesmo direito ou obrigação, é facultado a cada um deles, individualmente, postular ou defender-se em juízo em nome de todos. ${ }^{64}$ São os casos das obrigações ou direitos de natureza solidária, como os que ligam os condôminos em relação ao bem comum (CC, art. 1.314), os herdeiros em relação à herança ainda não partilhada (CC, art. 1.791), os responsáveis civis em relação ao dano (CC, art. 942), os credores de obrigação indivisível (C.C, arts. 259-260), as partes que assim dispuserem (C.C, art. 264-265) etc.

Movida a demanda por apenas um ou alguns dos titulares solidários de um direito, ou proposta ela perante um ou alguns dos obrigados solidariamente, surge a questão de se saber como a coisa julgada produzida no processo relaciona-se com aqueles que não integraram a relação jurídica processual, mas que mesmo assim são atingidos pela eficácia da sentença.

62. Lobo Da CosTa, Assistência, p. 197. Para Dinamarc'o, trata-se do fenômeno da eficácia preclusiva da coisa julgada, pelo qual o assistente fica impedido de discutir novamente os fundamentos que serviram de base à decisão cujos efeitos se cristalizaram (CPC, art. 471 - Coisa julgada e intenvenção de terceiros, p. 35-36). Já BAPTISTA DA SILVA sustenta que o assistente fica vinculado apenas à motivação, e não ao decisum (Curso de processo civil, p. 278). SCARPINELLA BUENO assume posição idèntica à deste último, enquanto T ALAMNI entende subordinar-se o assistente tanto aos motivos quanto ao dispositivo (Partes e terceiros no processo civil brasileiro. p. 160, e Partes, terceiros e coisa julgada. p. 228 , respectivamentc).

63. LOBO DA COSTA, Assistência, p. 198; DINAMARCo, Instinuições de direilo processual civil, v. 2, p. 389; Baptista DA Silva, ('urso de processo civil, p. 278; TALAMINI, Pates, terceiros e coisajulgada, p. 228.

64. GOMES, Obrigações, p. 60 
Para parte da doutrina, o fenômeno operado nesses casos í o da substituição processual. Aquele que atua em juízo o faz em nome também dos demais credores ou devedores solidários, de modo que o resultado derivado do processo se estende normalmente aos sujeitos que dele não participaram pessoalmente, mas foram substituidos por titular da mesma relação jurídica. Nessa linha de raciocínio, a coisa julgada incidente sobre os efeitos da sentença ali proferida também abarca esses sujeitos não-litigantès. ${ }^{6.5}$

Outra parte da doutrina rejeita a tese de que a coisa julgada derivada de processos desenvolvidos dessa forma pudesse vincular também aqueles titulares do direito ou da obrigação que não figuraram como partes. Partindo da premissa de que tal solução violaria os preceitos constitucionais que impedem a extensão da res iudicata a quem não fez valer suas razoes em juizo (CF, art. $5^{\circ}$, incs. XXXV, LIV \& LV), invocam a diferença entre efícácia da sentença e autoridade da coisa julgada, para afirmar que a primeira afeta a todos os unidos solidariamente, mas a segunda se restringe somente às partes do processo. ${ }^{66}$

De acordo com essa posição, se os credores solidários, após sofrerem os efcitos da sentença de procedência em processo de que não tomaram parte, não podem mover outra demanda versando o mesmo direito, não é porque estão sujeitos à imutabilidade da coisa julgada, mas sim em razão de faltar-lhes interesse jurídico para tanto (CPC, art. 267, inc. VI). Afinal, scria inútil tutela jurisdicional que thes conferisse o que já obtiveram em processo movido por um dos credores solidários. Por outro lado, caso a primeira sentença seja de improcedência, a qualquer dos titulares do direito que não tenham estado no processo, a despeito de sofrerem os efeitos negativos ali produzidos, é dado mover nova demanda postulando resultado diferente. Nessa hipótese, por óbvio, não há que se thes negar interesse jurídico na obtenção do provimento favorável. ${ }^{67}$

65. DinamarCo, Instituições de direito processual civil, v. 3. p. 322, e Coisa julgada e intenenção de terceiros, p. 20; SCARPINELLA BUENo, Partes e terceiros no processo civil brasileiro, p. 304.

66. LIEBMAN, Sentença e coisa julgada, p. 316, e Fifficacia ed autorità della sentenza, p. 162; TAlamini, Partes, terceiros ' coisa julgada, p. 212-213.

67. Talamin. Parles, terceiros e coisa julgada. p. 214. Apesar de partir de premissas teóricas substancialmente diferentes, MESQUITA chega aos mesmos resultados práticos (A coisajulgada no código do consumidor, p. 31-32). 
O mesmo raciocínio é aplicado aos casos de devedores solidários. Condenado um deles à prestação devida, é certo poder ele se valer de seu direito de regresso para cobrar em juízo dos demais, que não participaram do processo, a quota proporcional que incumbe a cada um. Essa possibilidade, no entanto, é manifestação da eficácia da sentença, e não da incidência da coisa julgada. A autoridade desta. com efeito, não vincula os devedores não-litigantes, que podem, assim, alegar em sua defesa, na demanda regressiva, todos os argumentos disponíveis em seu favor, inclusive os que já tenham sido julgados no primeiro processo. ${ }^{68} \mathrm{O}$ inconveniente de eventuais decisões contraditórias seria prevenido com o recurso ao chamamento ao processo, por meio do qual o devedor primeiramente acionado colocaria a seu lado no pólo passivo os demais co-devedores, que ficariam assim subordinados à coisa julgada, na condição de partes (C.PC, arts. 77 a 80$){ }^{69}$

A solução alvitrada para o caso dos devedores solidários estender-se-ia a todas as demais hipóteses de demanda regressiva, como a do segurado em face do segurador, do fiador diante do afiançado, do credor em caso de eviç̧ão ${ }^{70}$ etc. Em nenhuma delas, o réu da ação de regresso estaria vinculado, por força da coisa julgada, ao quanto decidido no processo em que condenada sua contraparte. Apesar de sujeito à eficácia da sentença ali prolatada, teria às mãos todos os fundamentos que pudessem ser utilizados em seu favor, ainda que já expressamente rechaçados naquele primeiro processo. No caso das obrigações regressivas, evitar-se-ia o inconveniente dos julgados contraditórios por meio da denunciação da lide ao garantidor (CPC, art. 70). ${ }^{71}$

68. LiebimAn, Sentença e coisa julgada, p. 316, e Efficacia ed autorità della sentenza, p. 163.

69. TAlaminI, Partes, terceiros e coisa julgada, p. 215. Para LIEBMAN, "são possiveis julgados contraditórios, e esse é um grave inconveniente; mas, mesmo assim, menos grave do que o de alargar, como mancha de óleo, os efeitos de uma sentença errônea e de sujeitar-lhe até quem. se chamado a juizo, turia evitado o erro e pode agora demonstrá-lo" (Sentença e coisa julgada, p. 316).

70. Quanto à evicção, há disposição expressa da lei material no sentido de que a responsabilização do alienante depende de sua participação no processo movido contra o adquirente (CC, art. 456), a qual se dá por meio da denunciação da lide (CPC, art. 70, inc. I).

71. Talamini, Partes, terceiros, coisa julgada, p. 217. 


\subsection{Sucessão processual.}

É tradicional a afirmação de que a coisa julgada atinge os sucessores das partes, tenham eles integrado ou não a relação processual. ${ }^{72}$ No Brasil, tal assertiva se apóia no disposto no art. $42, \S 3^{\circ}$. do Código de Processo Civil. ${ }^{73}$ A adequada análise do problema, no entanto, ao contrário do que entendem alguns, ${ }^{74}$ pressupõe o exame dos diferentes momentos e naturezas da sucessão, isto é, se ela ocorre antes, durante, ou depois da propositura da demanda, ${ }^{75}$ e se deriva de ato inter vivos ou causa mortis.

Por meio da sucessão, seja a título singular ou universal, inter vivos ou mortis causa, o feixe de direitos e/ou deveres incidente sobre a pessoa sucedida, em razão da posição que ostentava frente ao objeto. é transferido ao sucessor. Dessa forma, este passa a ser o único titular das situações jurídicas subjetivas relacionadas com o objeto da transferência.

Tal constatação permite ver com clareza o que ocorre nos casos em que a sucessão, de qualquer modalidade, se dá ainda antes da instauração do processo. Transferidos os direitos e/ou deveres sobre os quais versará a causa, o sucessor - novo titular deles passa a ser o único sujeito dotado de legitimidade para figurar em qualquer dos pólos da relação processual. O sucedido, se incluído na demanda, será parte ilegítima, motivo em que se deverá fundar o decreto de extinção do processo sem julgamento do mérito (CPC. art. 267, inc. VI). Sendo assim, o sucessor estará vinculado à autoridade da coisa julgada incidente sobre a sentença de mérito pela simples e normal razão de que foi parte no processo (CPC, art. 472). Não o sendo, a demanda não terá condições de prosperar. ${ }^{76}$

72. GOLDSCHMIDT, Livilprozessrecht, p. 328; LENT, Livilprozessrecht, p. 251-252; ROSENBERG, Lehrbuch des deutschen zivilprozessrechts, p. 482-483; CHIOVFND $\Lambda$, Istituzioni di diritto processuale civile, p. 416; COUTURL, Fundamentos del derecho procesal civil, p. 423-424.

73. DINAMARCo, Instituições de direilo processual civil, v. 2, p. 272, e v. 3, p. 321-322; BAPTISTA DA SIlva, Curso de processo civil, v. I, p. 501; PORTO, Comentários ao código de processo civil, v. 6, p. 210; CALIXTO E MARINS, Eficácia da sentença e coisa julgada perante terceiros, p. 50.

74. CALIXTU e MARINS, Eficácia da sentença e coisa julgada perante terceiros, p. 50.

75. Neste último caso, pressuposta a citação do réu nos termos do art. 219 do Código de Processo civil, apta a tornar litigiosa a coisa.

76. MONIZ dE ARAGÃo, Observações sobre os limites subjetivos da coisa julgada, p. 12; TALAMIN, Purtes, terceiros e coisa julgada, p. 219-220. 
A seu turno, se a sucessão tem lugar após o término do processo, a coisa julgada, integrada que está ao "patrimônio jurídico" do sucedido. se transfere ao sucessor, como tudo o mais pertencente ao feixe de direitos e/ou deveres relacionados com o objeto da sucessão. Não há que se falar, também aqui, em extensão da res judicata a quem não foi parte no feito. Afinal, em rigor, sequer se trata de questão de indole processual. É a própria lei material que rege a cessão de direitos e/ou obrigações, situação em que se acha a coisa julgada depois de formada. Ela se transfere, assim, à esfera jurídica do sucessor, da mesma forma que qualquer direito ou dever, quer por ato inter vivos ou causa mortis. ${ }^{77}$

Análise mais atenta merece a hipótese de sucessão no curso do processo. Derivando ela da morte de um dos litigantes, o processo é suspenso (C.PC, art. 265, inc. I), até que o espólio (por seu inventariante) ou os sucessores, por meio da habilitação (C.PC, arts. I.055 ss.), passem a ocupar o lugar do sucedido na relação processual (CPC. art. 43). Essa "substituição" - em sentido atécnico, apesar da dicção do art. 43 da parte falecida pelo(s) seu(s) sucessor(es) independe de autorização da parte contrária, e é condição para o prosseguimento do feito. Sendo assim, a coisa julgada que se formar nesse processo atingirá normalmente os sucessores, os quais terão sido partes na ação. ${ }^{78} 79$

De outra parte, decorrendo a sucessão de ato inter vivos, é preciso distinguir a situação em que o ingresso do sucessor na relação processual, no lugar do sucedido, é autorizado pela parte contrária, daquela em que tal não é permitido (CPC, art. $42, \S 1^{\circ}$ ). Na primeira hipótese, o sucessor adquire a qualidade de parte e, como tal, está sujeito normalmente à autoridade da coisa julgada. O mesmo ocorre se, desautorizada sua entrada no feito no lugar da parte sucedida, o sucessor vale-se da prerrogativa de intervir no feito na qualidade de assistente litisconsorcial do sucedido $\left(C P C\right.$, art. $\left.42, \S 2^{\circ}\right) .{ }^{80}$ Ficará ele, aqui também por ter se tornado parte, submetido à

77. MONIZ DE ARAGão, Observações sobre os limites subjelivos da coisa julgadu, p. 12; TALAMIN!, Partes, terceiros e coisa julgada. p. 222.

78. DINAMARCo, Instituições de direito processual civil. v. 2, p. 272; CARNEIRO, Intervenção de terceiros, p. 43: MONIZ DE ARAGÃO. Observações sobre os limites subjetivos da coisa julgada, p. 12; T ALAMINI, Partes, terceiros e coisa julgada, p. 220.

79. Mesmo raciocínio se aplica, mutatis mutandis, às hipóteses de sucessão "conusamortis" de pesscas juridicas.

80. MONIZ DE ARAGĀO, Observações sobre os limites subjetivos da coisa julgada, p. I3; TALAMINI, Parles, terceiros e coisa julgada, p. 220. 
imutabilidade operada pela coisa julgada, ainda que sob a forma específica da "eficácia da intervenção" (supra, n. 4.1). ${ }^{81}$

Não ingressando o sucessor inter vivos no lugar do sucedido no processo. ainda assim há que se fazer uma distinção. Sc aquele encontrava-se reconhecidamente de boa-fé, isto é, não fora informado da existência do processo, ou não tinha condições de sabê-lo, a partir da diligência ordinária do homem comum, de acordo com as informações constante dos registros públicos ou do cartório distribuidor, a coisa julgada derivada da causa de que não foi parte não lhe é oponivel ${ }^{82}$ Caso contrário. o sucedido, permanecendo na relação processual, atuará como autêntico substituto processual do sucessor (infra, n. 4.4), ${ }^{83}$ e aí sim a coisa julgada lá formada imporá sua autoridade a este, a despeito de sua ausência na ação (CPC, art. $\left.42, \S 3^{\circ}\right) .{ }^{84}$

\subsection{Substituição processual.}

Chama-se substituto processual aquela pessoa fisica ou jurídica a quem a lei, em excepcionais e expressas situações, confere legitimidade - chamada portanto extraordinária, em contraposição à ordinária do art. $6^{\circ}$ - para atuar em juízo em nome próprio, ${ }^{85}$ mas no interesse de outro sujeito ${ }^{86} \mathrm{O}$ legitimado extraordinário figura, assim,

81. MONIZ DE ARAGião, Observações sobre os limites subjetivos da coisa julgada, p. 13; DINAmarco, Coisa julgada e intervençâo de terceiros, p. 34-36. Para TAlamini, o assistente litisconsorcial, ou qualificado. fica subordinado à coisa julgada da mesma forma que uma parte, haja vista a lei conferir-lhe o tratamento de um litisconsorte (CPC, art. 54) (Partes, tercerros e coisajulgada, p. 227228). SCARPINELLA BUENO também entende que o assistente qualificado vincula-se à coisa julgada material, mas não por ser parte, e sim porque a relação juridica de que é parte (em sentido material) já está deduzida em juizo (Partes e terceiros no processo civil brasileiro, p. 161-163).

82. MONIZ DE ARAlī̃o, Observações sobrc os limites subjetivos da coisa julgada. p. 13; TAl .MMN. Parles, terceiros e coisa julgada, p. 220-221.

83. CARNEIRO, Intervenção de terceiros, p. 42.

84. CHIOvENDA, Istituzioni di diritlo processuale civile. v. 1, p. 416; MONIZ DE ARAGÃO, Observações sobre os limites subjetivos da coisa julgada, p. 13; DINAMARCO. Instituições de direito processual civil, v. 2, p. 272, e v. 3, p. 321; T ALAMINI, Parles, terceiros e coisa julgada, p. 221-222. Afinal, "se queste ultime persone no fossero vincolate dal giudicato, sarebbe priva di senso la prosecuzione del processo nei confronti dell'antico titolare, resa necessária dal \$ 265; da un lato l'avversario non protrebbe ricevere alcuna utilitá dalla vittoria in giudizio, dall' altro il sucessore non potrebbe esser sicuro della sua posizione nemmeno dopo il riconoscimento del diritto del sun dante causa" (LENT, Zivilprozessrecht, p. 252).

85. Diferenciando-se assim do representante.

86. CHOVENDA, Istituzioni di diritlo processuale civile, v. 2, p. 252-253; CINTRA, Estudo sobre a substituição processual no direilo brasilciro, p. 24. 
como parte no processo, apesar de não ser parte na relação jurídica material controvertida. $^{87}$ Os efeitos da sentença projetam-se naturalmente sobre o substituído, titular que é dos interesses em jogo. Resta saber como se comporta a disciplina da coisa julgada nesses casos.

A multiplicidade de hipóteses de substituição processual torna conveniente sua analise apartada, conforme se trate de demandas individuais ou de ações coletivas.

\subsubsection{Tutela individual.}

Goza de ampla e tradicional aceitação a tese de que a coisa julgada do processo conduzido pelo substituto processual estende sua autoridade à esfera de direitos do substituído. ${ }^{88}$ Essa visão decorre, intuitivamente, do fato que "seria absurdo que a lei autorizasse a qualquer alegar em juizo direitos alheios e, ao mesmo tempo, não reconhecesse à sua atividade plena eficácia com referência aos dircitos alegados" 89

Plenamente identificada a diferença entre a eficácia produzida pela sentença e a coisa julgada sobre ela incidente, no entanto, aquela perplexidade não impõe como conseqüência necessária a extensão da coisa julgada em face dos substituídos. Absurda seria a não produção, perante eles, dos efeitos da sentença, conclusão não imperativa em se tratando da coisa julgada, cuja imposição indiscriminada a quem não haja sido parte no processo esbarra em diversas garantias constitucionais (CF, art. $5^{\circ}$, incs. XXXV, LIV e LV, supra, n. 2).

Considerações dessa ordem levam boa parte da doutrina a recusar a extensão aos substituídos da coisa julgada produzida em processo de que não

87. CINTRA, Fstudo sobre a substituição processual no direito brasileiro, p. 29; FREDERICO MARQUES, Instituiçōes de direito processual civil, v. 2, p. 175-176.

88. ChIOvLnda. Istituzioni di diritlo processuale civile v. 1. p. 416, e v. 2, p. 253: LIEBMAN, Efficacia ed autorilà della sentenza, p. 97; DINAMARCO. Instituiçóes de direilo processual civil. v. 2, p. 310. e v. 3. p. 321 -322; CARNEIRO, Intervenção de terceiros. p. 34: CINTRA, Esthido sobre a substituição processual no direito hrasileiro, p. 32-33. e Comentários ao código de processo civil, v. 4, p. 319.

89. CHIOVENDA, Istituzioni di diritto processuale civile, v. 2, p. 255. 
participaram (ou não tiveram oportunidade para tal). ${ }^{90}$ Para Moniz de Aragão, ou é conferida ao substituído a oportunidade de tomar parte na relação jurídica processual, ou não é dado lhe tornar vinculantes os efeitos da sentença. ${ }^{91}$ Seguindo linha bastante próxima, Talamini entende que a extensão da coisa julgada ao substituído se justifica apenas se $\left(1^{\circ}\right)$ teve ele oportunidade de mover a demanda e deixou de fazê-lo, ou se $\left(2^{\circ}\right)$ tinha ele (ou deveria ter) ciência da existência do processo e, nessa hipótese, se the era possivel participar do contraditório na condição de assistente. Como exemplo de sujeição legítima do substituído, cita o caso do sucessor, na hipótese do art. $42, \S 3^{\circ}$ (supra, n. 4.3). Contrariamente, o legitimado ordinário à propositura de demanda investigatória de paternidade não ficaria vinculado à coisa julgada produzida no processo anteriormente movido pelo Ministério Público (lei n. $8.560 / 92$, art. $2^{\circ} \S \S 4^{\circ} \mathrm{e}$ $\left.5^{\circ}\right)^{92}$

\subsubsection{Tutela coletiva.}

Como dito, merece atenção singularizada a substituição processual levada a cabo nas chamadas ações coletivas, uma vez que os direitos em jogo nessa modalidade de tutela detêm especificidades que tornam conveniente -. ou mesmo impõem - um tratamento processual diferenciado em relação ao conferido à tutela individual. Para os fins que nos interessam mais de perto no presente estudo, com efeito, a natureza transindividual dos direitos a que se dirigem as ações coletivas sugerem a uniformidade dos resultados do processo para todos os sujeitos da relação material controvertida. ${ }^{93}$

90. Protu PISANI, Lezioni sul prucesso civile. p. 402; MONIZ DF ARAGÃo, Observações sobre os limites subjetivos da coisa julgada, p. 14-15; T ALAMINI, Partes, terceiros e coisa julgada, p. 222-225. Segundo o autor italiano, "è opiniune oramai pacifica in dottrina e in giurisprudenza che al processo debba partecipare in veste de litisconsorte necessario ex art. 102, anche il legitimato ordinario titolare attivo o passivo del raporto dedolto in giudizio".

91. MONIZ DE ARAGÃo, Observą̃ões sobre os limites subjetivos da coisa julgada, p. 15.

92. T Alamini, Partes. terceiros e coisa julgada, p. 224-225.

93. BEDAqUe. Direito e processo, p. 94-96: GRNivere, O novo processo do consumidor. p. 131, e.A coisa julgada perante a constituição, a lei da ação civil pública, o estatuto da criança e do adolescente e o código de defesa do consumidor. p. 147; GDI. Coisa julgada e litispendência em ações coletivas, p. 57 ss.; SOSA, La cosa juzgada en los procesos colectivos, p. 457; MARCATO (et. al.), Código de processo civil interpretado, p. 1.443. 
Em atenção a tal rcalidade, boa parte da doutrina sustenta que a coisa julgada emanada das ações coletivas opera secundum eventum litis, isto é, impõe sua autoridade para todos os titulares da relação material, ainda que não litigantes, apenas em caso de procedência do pedido. ${ }^{94}$ É o que extraem da dicção das normas do art. 103 , incs. I, II e III, e $\$ \S 1^{\circ}, 2^{\circ}$ e $3^{\circ}$, do CDC (aplicáveis à generalidade das demandas coletivas), ${ }^{95}$ que, de um lado, afirmam a autoridade erga omnes e ultra partes da coisa julgada nos processos versando direitos difusos e coletivos, exceto no caso de improcedência por insuficiência de provas, e a autoridade erga omnes da res judicata tratando-se de direitos individuais homogêneos, apenas para beneficiar seus titulares; de outro, ressalvam expressamente que os interesses dos individuos titulares dos direitos em litígio, seja qual for a natureza destes, não são prejudicados pela coisa julgada produzida no processo de que não tenham participado.

O propósito declarado dessas disposições, segundo os próprios autores do anteprojeto de lei do Código do Consumidor, foi impedir a extensão indiscriminada da coisa julgada aos titulares do direito que não hajam tomado parte no feito, o que colidiria com a garantia constitucional do contraditório. Daí por que, segundo eles, essa sujeição ocorreria apenas para beneficiá-los, nunca para prejudicá-los. ${ }^{96}$

Essa visão é criticada por Mesquita. Para o professor paulista, a regra da autoridade inter partes da coisa julgada não foi quebrada pelo Código do Consumidor, em relação aos indivíduos titulares dos direitos litigiosos. Isso pela simples razão de que os elementos da ação coletiva em nada se confundem com os elementos de eventual demanda individual por eles movida. O objeto e a causa de pedir de ambas seriam sempre discrepantes, de modo que a coisa julgada formada nas ações coletivas em nada afetaria a propositura de demandas individuais pelos titulares do direito. As disposições do Código do Consumidor que impedem a formação da coisa julgada em

94. Por todos, GRINOVER (et al.), Código brasileiro de defesa do consumidor comentado pelos autores do anteprojeto, p. 839; GRINOVER, O nuvo processo do consumidor. p. 133, e A coisajulgada perante a constituição, a lei da ação civil pública, o estatuto da criança e do adolescente e o código de defesa do consumidor, p. 149.

95. É o que se extrai dos arts. $1^{\circ}$, inc. IV, e 21 , da Lei da Ação Civil Pública. Cf. GRINOVER(et al.), Código brasileiro de defesa do consumidor comentado pelos autores do anteprojelo, p. 843 .

96. GrinuVtr (et al.), Código hrasileiro de defesa do consumidor comentado pelos autores do anteprojeto, p. 839: GRINOVER, O novo processo do consumidor. p. 135. 
prejuizo dessas pretensões individuais seriam, portanto, absolutamente inúteis (CDC, art. $103, \S \S 1^{\circ}, 2^{\circ}$ e $\left.3^{\circ}\right) .^{97}$

Também Dinamarco recusa-se a aceitar aqui a existência de uma coisa julgada erga omnes para beneficiar os indivíduos, ao menos tratando-se de direitos individuais homogêneos. Para ele, o que obstaria a que os titulares desses direitos rediscutissem para si a matéria da ação coletiva já julgada procedente seria a falta de interesse juridico em alterar o que lhes é favorável (CPC, art. 267, inc. VI). O que os atinge, assim, não é nada mais quc a própria cficácia da sentença coletiva. ${ }^{98}$ Não se vê por que esse raciocínio não possa ser estendido também aos direitos difusos e coletivos, diante do disposto no art. $103, \S \S 1^{\circ}, 2^{\circ}$ e $3^{\circ}$ do Código do Consumidor.

O que ninguém nega, por óbvio, é a vinculação das próprias partes litigantes à coisa julgada (exceto em caso de improcedência por insuficiência de provas, tratando-se de direitos difusos e coletivos, hipótese em que não há formação da coisa julgada material - CDC, art. 103, incs. I e II), sejam elas apenas o autor coletivo e o réu, sejam também os indivíduos sujeitos da relação controvertida que tenham intervindo no processo na condição de litisconsortes (CDC, art. $\left.103, \S 2^{\circ}\right)$. Mas nesses casos não há nenhuma exceção à regra geral da autoridade inter partes da coisa julgada (CPC, art. 472).

Com relação aos demais legitimados extraordinários que não participaram da ação, a opinião prevalecente é de que a coisa julgada espalha sua força também para eles, operando secundum eventum litis (CDC, art. 103, incs. I e II e III; Lei da Ação Civil Pública, art. 16). Em outras palavras, todos os sujeitos legitimados à propositura da ação coletiva ficam sujeitos à coisa julgada, exceto em caso de improcedência por insuficiência de provas, tratando-se de direitos difusos ou coletivos, ou exceto em qualquer caso de improcedência, tratando-se de direitos individuais homogêneos. ${ }^{99}$

97. MESQUITA, A coisa julgada no código do consumidor, p. 37-38.

98. Instituições de direilo processual civil, v. 3, p. 213 e 305.

99. GRINOVER (et al.), Código brasileiro de defesa do consumidor comentado pelos autores do anteprojelo, p. 855 ss.: GIDI, Coisa julgada e litispendência em ações coletivas, p. 116-117: TALAMIN, Parles, terceiros e coisa julgada, p. 238. A opinião de PEDRO DINAMARCO apenas reaclva que os dimais legitimados extraordinários também ficam impedidos de mover nova ação coletiva em caso de improcedência de demanda versando direitos individuais homogêneos, dado o silêncio da lei em repetir a autorização expressa nesse sentido prevista em relação aos difusos e coletivos (CDC, art. 103, incs. I e II) (Ação civil puiblica, p. 102-103). 
Mesquita também lança crítica a esse entendimento. Invoca a distinção de Liebman entre eficácia da sentença e autoridade da coisa julgada para dizer que os demais legitimados são afetados por aquela em caso de procedência da demanda, não por esta. ${ }^{100} \mathrm{O}$ que impede os outros legitimados à ação coletiva - que, apesar de não terem participado do processo já findo, heneficiaram-se de seus resultados de mover nova demanda com o mesmo objeto, não é a força da coisa julgada, mas simplesmente a falta de interesse juridico (CPC, art. 267, inc. VI), dado que em nada lhes aproveitaria uma segunda sentença atribuidora do mesmo bem da vida. Segundo esse entendimento, portanto, não se trata de impor a autoridade da coisa julgada a quem não haja integrado o processo bem sucedido, a fím de beneficiá-los: a questão resolve-se na inexistência de interesse jurídico por parte dos demais legitimados para mover nova demanda coletiva, depois de já julgada procedente a primcira. A previsão legal da coisa julgada erga omnes em caso de sucesso da ação coletiva, assim, scria absolutamente desnecessária. ${ }^{\mid 01}$ Em sua opinião, a única exceção aos limites subjetivos da coisa julgada trazida pelo Código do Consumidor é a extensão de sua autoridade aos demais legitimados às ações coletivas, versando direitos difusos ou coletivos, no caso de improcedência do pedido por motivo outro que não a insuficiência de provas. ${ }^{102}$

Quer se adote a visão da doutrina dominante com relação à extensão da coisa julgada a todos os legitimados às ações coletivas, quer se adote a posição mais restritiva sustentada por Mesquita, afirma-se que as garantias constitucionais subjacentes à regra geral da autoridade inter partes da coisa julgada não são violadas nesse caso. Isso porque a lei instituiu mecanismos voltados a assegurar tanto a adequada representação dos tilulares dos direitos pelos legitimados extraordinários em juizo quanto a impedir o mau uso da ação coletiva, o que torna constitucional a imposição da coisa julgada àqueles entes legítimos que não litigaram. Para esse fim se prevê, por exemplo, a participação necessária do Ministério Público (Lei da Ação Civil

100. A sempre presente distinção entre ıficácia da sentença e autoridade da coisa julgada também pode ser empregada para a regra constante do art. 104 do Código do Consumidor. Se o autor da demanda individual, cientiticado da existência de ação coletiva versando seus interesses, não requerer a suspensão de seu processo em trinta dias, ele não deixará de ser beneficiado pelos "efeitos da coisa julgada erga omnes ou ultra partes", mas sim pela própria eficácia natural da sentença, que terá excluido de seu campo de incidência aquele sujeito (TALAMINI, Partes, terceiros e coisa julgada, p. 236).

101. MESQUITA, A coisa julgada no código do consumidor. esp. p. 35-38; TALAMINI, Potex, loceims e coisa julgada. p. 235.

102. MESQUITA, A coisa julgada no código do consumidor. p. 36. 
Pública, art. $5^{\circ}, \S 1^{\circ}$ ), a possibilidade de intervenção dos demais legitimados é dos titulares do direito como litisconsortes do autor (Lei da Ação Civil Pública, art. $5^{\circ} \S 2^{\circ}$; CDC, art. 103, $\S 2^{\circ}$ ), o necessário prosseguimento do feito pelo Ministério Público ou outro legitimado em caso de desistência ou abandono (Lei da Ação Civil Pública, art. $5^{\circ}, \S 2^{\circ}$ ); e a não-formação de coisa julgada em caso de insuficiência de provas (direitos difusos e coletivos) ou de improcedência (direitos individuais homogêneos). ${ }^{103}$

No caso particularizado da ação popular, a coisa julgada impõe-se erga omnes em caso de procedência ou improcedência do pedido, de modo a impedir que qualquer cidadão, ainda que não tenha tomado parte no processo, pleiteie em juízo resultado diferente, com base nos mesmos fundamentos. A coisa julgada não operaria desse modo apenas na hipótese de improcedência da demanda por insuficiência de provas (Lei da Ação Popular, art. 18). ${ }^{104}$ Essa extensão da força vinculante da sentença não padece de inconstitucionalidade por razões semelhantes às analisadas acima (Lei da Ação Popular, art. $6^{\circ}, \S \S 3^{\circ} .4^{\circ}$ e $5^{\circ}$, arts. $9^{\circ}$ e 19$)$.

\subsection{Ações de estado.}

Conforme dispõe a parte final do art. 472, do Código de Processo Civil, "nas causas relativas ao estado de pessoa, se houverem sido citados no processo, em litisconsórcio necessário, todos os interessados, a sentença produz coisa julgada em relação a terceiros"

À primeira vista, esse dispositivo parece abrir uma exceção à regra geral sobre a autoridade inter partes da coisa julgada, prescrevendo que esta se imporá também a "terceiros". nas causas que tenham por objeto o estado familiar (status familiae) ou o estado de cidadania (status civitatis). ${ }^{105}$ Tal não corresponde à verdade. contudo.

103. TAlamini, Parles, terceiros e coisa julgada, p. 238-239; GRINOVER, O novo processo do consumidor, p. 133-135; SOSA, La cosa juzgada en los procesos colectivos. p. 459 ss..

104. T AI AMINI, Partes. terceiros e coisa julgada, p. 239-240; GRINOVFr, A coisajulgada perante a constituição, a lei da ação civil pública, o estatuto da criança e do adolescente c o código de defesa do consumidor, p. 148.

105. MONIz DE ARAGão, Observações sobre os limites subjetivos da coisa julgada, p. 17; MARCATO, Código de processo civil interpretado, p. 1.443. 
De acordo com o que determina a prescrição em foco. todos aqueles dotados de interesse jurídico na pretensão relativa ao estado de pessoa devem ser partes na relação processual, em litisconsórcio necessário. Isso quer dizer que, ausente ao menos um desses interessados, a sentença ainda assim proferida é ineficaz perante todos, segundo prevê o art. 47 do Código de Processo Civil e confirma a doutrina. ${ }^{106} \mathrm{E}$ se o provimento jurisdicional é desprovido de eficácia, não há substrato sobre o qual incidir a autoridade da coisa julgada - em face de quem quer que seja , a qual, sendo uma qualidade dos efeitos da sentença, inexistirá onde estes não existam (supra, $\mathrm{n}$. 3). ${ }^{107}$

Por outro lado, se todos os interessados juridicamente no resultado do processo foram incluídos como partes, em litisconsórcio necessário, a sentença é apta a produzir efeitos, e a coisa julgada incidente sobre eles vincula precisa e exclusivamente as partes, e mais ninguém. Afinal, aqueles que não estiveram presentes na relação processual são, a contrario sensu, desinteressados e, portanto, desprovidos de legitimidade e interesse jurídico para pleitear $\mathrm{cm}$ juízo resultado diferente quanto à pretensão já julgada, que não lhes diz respeito (CPC, arts. $3^{\circ}$ e 267 , inc. VI).

Ao falar impropriamente em "coisa julgada em relação a terceiros", a disposição ora comentada pretendeu, em verdade, referir-se à eficácia natural da sentença, a qual, como manifestação do poder do Estado, "existe e vale com respeitos a todos" 108 (supra, n. 3). ${ }^{109} \mathrm{O}$ que é natural, visto que a ninguém é dado questionar o estado de casado dos cônjuges, ou a filiação de alguém - a não ser os próprios titulares da relação material, que já terão participado do processo na condição de interessados. Se, no entanto, passada em julgado a sentença, alguém se afirmar titular do direito litigioso, terá ele legitimidade para rediscutir a questão, e não se lhe poderá opor a objeção de coisa julgada, uma vez que não participara do processo - e era um "interessado", litisconsorte necessário (CPC, art. 47). ${ }^{110}$

106. Frederico MARQUeS, Instituições de direito processual civil, v. 2, p. 185; DinamarCo, I.itisconsórcio, esp. p. 111 e 263.

107. Dinamarco, Relativizar a coisa julgada material, p. 248.

108. CHIOvENDA. Istituzioni di diritto processuale civile. p. 414.

109. LIEBMAN, Efficacia ed autorità della sentenza, p. 138 ss., e La cosa giudicatu nelle questioni di stalo. p. 201; MESQUITA, A coisa julgada no código do consumidor, p. 24-25.

110. TAlamini, Partes, terceiros e coisa julgada, p. 230. 
Sendo assim, a segunda parte do art. 472 não constitui exceção, mas somente especifica a rugra geral estatuida na primeira parte. Nas ações de estado, não há nenhuma subversão dos limites subjetivos da coisa julgada. ${ }^{11}$

\section{Conclusão.}

É hora de tentar extrair uma conclusão acerca da definição de terceiro. Como dito, essa busca deve sempre pautar-se por critérios funcionais. A relevância mesma da construção de um conceito - justificativa para a tarefa aqui empreendida -, está em sua operabilidade, isto é, na capacidade que ostente de conformar uma realidade e torná-la compreensível e manipulável pelo operador do direito. Com esses propósitos diretivos, mais que informativos, é que o intérprete colhe da realidade o objeto ou conjunto de objetos a ser(em) designados(s). A partir daí, formula uma definição propriamente estipulativa, ou uma "redefinição" (supra, n. 1). ${ }^{1 / 2}$

Foi essa ordem de idéias que motivou a identificação do âmbito da realidade para cuja referência o conceito de terceiro mostra-se útil, na esfera do processo civil. Para esse fim, procurou-se extrair do complexo processual aqueles fenômenos cuja manipulação faz normalmente uso desse termo. Partindo-se do léxico e do uso histórico, analisou-se também o tratamento dado a ele na doutrina e na legislação. Esse trabalho trouxe como resultado o encontro de dois cortes da realidade para cuja designação o conceito de terceiro faz-se operativo (supra, n. 2).

Em primeiro lugar, demonstrou-se que terceiro é apontado como o sujeito que está fora da relação processual. isto é, aquele que não é parte no processo, não é "sujeito do contraditório instituído perante o juiz" "113 Mostrou-se que essa noção de terceiro, completamente apartada de ligações com o direito material, é utilmente usada para designar todos aqueles que, por contraponto, não são titulares dos ônus,

111. LIEBMAN, La cosa giudicala nelle questioni di stato, p. 200-201, e Limites à coisa julgada nas questões de estado, p. 205-211; MONIZ DE ARAGÃO. Observações sobre os limites subjetivos da coisa julgada. p. 21; CINTRA, Comentários ao código de processo civil, p. 320; PORTO, Comuntáias ao código de processo civil. p. 216-217; CALIXTO e MARINS, Eficácia da sentença e coisa julgada perante terceiros, p. 51; T ALAMINI, Partes, terceiros e coisa julgada, p. 230.

112. FERRAZ JÚNIOR, Introdução ao estudo do direito - decisão, técnica, dominação, p. 36-39; WARAT, O direito e sua linguagem, p. 57: LOPES, As palavras e a lei, p. 27.

113. LIEBMAN, Mamuale di dirillu processuale civile. p. 89. 
faculdades, direitos e deveres específicos e inerentes à posição subjetiva ostentada pelas partes de um processo, pelos sujeitos integrantes da relação jurídica processual (supra, n. 2).

Em segundo lugar, viu-se o uso de terceiro como aquele que não se vincula à autoridade da coisa julgada. Essa significação antiquíssima remonta hoje à idéia de que não seria admissivel, à ciência processual erigida no Estado democrático de direito. restringir definitivamente os direitos daqueles que não tiveram oportunidade de fazer valer suas razões diante de um juiz. pelos meios franqueados pela lei. É o que se depreende dos principios do contraditório. da ampla defesa, do acesso à justiça e do devido processo legal. todos garantidos constitucionalmente (art. $5^{\circ}$, incs. XXXV. LIV e LV) (supra, n. 2).

Estipulados assim os dois objetos teórico-processuais em que o termo terceiro aparece com maior freqüência e portanto para os quais a elaboração de uma definição mostra-se mais proveitosa a esse ramo do direito -, fazia-se então necessário averiguar se o trato prático dos institutos do processo que lidam com o termo confirmava esses usos. Mais que isso, era preciso aferir se esse tratamento permitiria construir uma definição de terceiro que abrangesse ambas aquelas parcelas da realidade estipuladas. Com esse objetivo é que se analisaram os fenômenos da intervenção de terceiros. das obrigações solidárias. do direito de régresso, da sucessão processual, da substituição processual nas tutelas individual e coletiva e das ações de estado, em relação à coisa julgada e aos sujeitos situados dentro e fora do processo (supra, n. 4).

De tudo o quanto exposto, é lícito concluir, em primeiro lugar, que a prática processual confirma a designação de terceiro como aquele que não é part'́ no processo. No trato das chamadas "intervenções de terceiros" por exemplo, está-se sempre diante de mecanismo por meio do qual uma pessoa que não integra a relação processual passa a fazer parte dela, assumindo aquelas posições subjetivas inerentes à condição de parte em sentido processual, com seus ônus, faculdades, deveres etc., o qui acontece inclusive com o assistente (supra, n. 4.1. nota 59). Enquanto a intervenção não ocorre, portanto, o sujeito é terceiro em relação àquele processo.

Confirmada está, também, a independência da noção de terceiro processual $\mathrm{um}$ relação ao vinculo de direito substantivo, seja o narrado pelo autor, seja o existente de fato. Antes de intervir, por mais que seja parte da res in iudicium deducta, o sujeito é terceiro para fins processuais. Da mesma forma, aquelé que interveio, apesar de não ter legitimidade para tanto, ainda assim é parte no processo, até 
que dele seja excluido (pode alegar, recorrer, produzir provas; deve agir com "lealdade e boa-fé" responder por dano processual etc.). Os demais fenômenos estudados endossam esse entendimento, ao tratar do problema da autoridade da sentença perante sujeitos que não foram partes no liame processual - terceiros em relação ao processo, portanto. Por mais diversos que sejam os fundamentos e resultados do problema na sucessão, na substituição, nas ações de estado etc., trata-se sempre de saber se ao decidido no processo vincula-se apenas quem nele tomou parte ou também quem não (supra, ns. 4.2, 4.3, 4.4 e 4.5).

Vê-se, assim, que a designação, pelo termo terceiro, daquele que não é parte no processo, constitui uma definição per genus el differentiam precisa, nos termos apontados por Hart, ${ }^{1 / 4}$ que permite construir uma regra exata com base na qual pode ser verificada a correção do uso do vocábulo terceiro (supra, n. 1). Em todos os casos, quem é parte no processo não é terceiro.

As investigações em torno do conceito poderiam encerrar-se aqui, não fosse $o$ fato de que a definição acima aludida deixa de fora a outra esfera da realidade processual onde a noção de terceiro faz-se extremamente importante. Identificar aqueles que estão fora da relação processual nada diz (ou não diz o bastante) a respeito da relação entre terceiros e a coisa julgada. A definição referida peca, assim, pela insuficiência, visto não ser plenamente operativa diante do corte fenomênico relevante estipulado.

Diante disso, cumpre verificar se a prática também confirma aquele segundo significado do termo terceiro, ligado aos limites subjetivos da coisa julgada. Conforme procurou-se demonstrar nos tópicos anteriores (supra, n. 4), pode-se dizer que a regra geral, ainda hoje aplicada em nosso sistema na imensa maioria dos casos, é a de que a coisa julgada não atinge terceiros, mas somente as partes. ${ }^{115}$ Assim é, além de no ordinário das situações (CPC, art. 472; CF. art. $5^{\circ}$, incs. XXXV. LIV e LV), nas ações de estado, nas demandas que têm por objeto relações solidárias ou regressivas, na maior parte das contingências ligadas à sucessão no processo, e também na maioria dos casos de substituição, na tutela individual, e em relação à maior parcela das pessoas, nas ações coletivas. As intervenções de terceiros também confirmam esse uso, na

114. The concept of law, p. 18-21.

115. Para Couture, essa regra é mesmo o ponto de panida no trato da questão dos limites subjetivos da coisa julgada (Fundamentos del derecho procesal civil. p. 422-423). 
medida em que servem exatamente para estender aos intervenientes - até então terceiros, depois partes - a autoridade da coisa julgada. Antes de seu ingresso na lide, não é lícito submeter-Ihes a essa imunização, exatamente porque terceiros. ${ }^{116}$

A regra só seria necessariamente quebrada $\left(1^{\circ}\right)$ na sucessão processual, quando o sucessor, desautorizado a figurar no lugar do sucedido na causa, não interviesse no feito ( $\mathrm{CPC}$, art. $\left.42, \S 3^{\circ}\right),\left(2^{\circ}\right)$ na substituição processual individual, quando fosse franqueada ao substituído a oportunidade de ingressar no processo e ele não o fizesse, $\left(3^{\circ}\right)$ na substituição processual havida nas ações coletivas, em relação apenas aos demais legitimados extraordinários em caso de improcedência da demanda por razão diversa da insuficiência de provas, tratando-se de direitos difusos ou coletivos (CDC, art. 103, incs. I e II; Lei da Ação Civil Pública, art. 16), e (4) na substituição operada nas ações populares, nos casos em que o mérito do processo não fosse julgado com base em insuficiência de provas (Lei da Ação Popular, art. 18).

Como se vê. a segunda esfera da realidade referida pelo termo terceiro não permite uma definição da mesma categoria obtida para a outra, dotada de grau absoluto de precisão. Instituida em regra, a definição é obrigada a lidar com exceções num esquema mínimo, as acima citadas.

Talvez essa seja a razão por que parte significativa da doutrina, na ânsia por formular uma definição que se referisse a essa segunda realidade de forma também pura, tenha sustentado que sucessor e substituido não seriam "verdadeiros terceiros" 117 visto que atingidos pelo trespasse dos limites subjetivos da coisa julgada. Essa solução não parece a mais adequada, entretanto. O que seriam tais sujeitos, se não terceiros? Partes não, porque são pessoas externas à relação processual. não sendo portanto titulares das posições subjetivas inerentes a esse papel. Fora desse prisma, não parece haver solução satisfatória: a dualidade partes/terceiros não comporta um tertium genus, tampouco gradação. Ou o sujeito figura na relação processual, ou não. Chamá-los de "adequadamente representados" 118 tampouco resolveria o problema, dado que nada diria a respeito de sua posição quanto à relação processual - se partes ou terceiros.

116. DinamarCo, Coisa julgada e intervenção de terceiros, p. 25.

117. LIFBMAN, Efficacia ed autorità della sentenza, p. 96 e 97; MONTELEONE, Ilimitti soggettivi del giudicato civile. p. 177-178; GRINOVER, Código brasileiro de defesa do consumidor, p. 834; CALXIOe MARINS, Eficácia da sentença e coisa julgada perante terceiros, p. 50.

118. Grinover, Código brasileiro de defesa do consumidor. p. 834. 
Isso confirma, na verdade, que uma definição de terceiro não pode se referir a apenas um daqueles cortes da realidade, isoladamente considerado. Se o foco é deitado com exclusividade sobre a posição ocupada pelo sujeito em relação ao vínculo jurídico-processual, o resultado é insuficiente; se o objcto é cingido à vinculação ou não à autoridade da coisa julgada, ınfrentam-se os problemas acima expostos. Para ser o mais útil possivel, pretendendo referir-se a todo o espectro da prática processual em que se lança mão do termo, portanto, o conceito precisa coordenar aquelas duas realidades. Só assim é possível evitar inconvenientes como aqueles.

Chcga-se, assim, à definição de tercciro como o sujeito que não é parle de determinado processo e, portanto, não pode ficar submetido à autoridade da coisa julgada lá formada. Fla não pretende ignorar a existência daqueles casos excepcionais em que, mesmo fora da relação processual, os sujeitos vinculam-se à res judicata. Tais pessoas não deixam de ser terceiros, apesar desse fato. F. isso em nada desmerece a definição; apenas mostra não ser possível construir um conceito de terceiro, que se pretenda maximamente útil. nos estritos lindes daquela modalidade tida por Hart ${ }^{119}$ como a mais simples, com grau de precisão absoluto. Na exata medida do aumento da complexidade do plano de referência do termo, é preciso admitir o aparecimento de "casos de fronteira", isto é, situações em que não se fazem presentes todas as caracteristicas integrantes da definnição, mas às quais apesar disso o termo se estende. ${ }^{120}$

A vantagem obtida com tal ampliação é tornar identificável pelo conceito todo o corte fenomênico em que o recurso à idéia de terceiro mostra-se útil, no direito processual. A definição aqui estipulada refere-se tanto ao primeiro âmbito da realidade, de caráter técnico-processual (não-parte), quanto ao segundo, com matriz na ordem constitucional (não sujeição à coisa julgada), evitando assim os problemas derivados da consideração exclusiva de um ou de outro.

A definição aqui proposta mostra, ademais, serem de todo inconvenientes as tentativas de conceituar terceiro conforme integre ele ou não a "lide" isto ¿̇. a relação litigiosa descrita pelo autor. Levando às últimas conseqüências a definição de parte proposta por ('hiovenda, ${ }^{121}$ essa posição reputa parte somente aquele que pede e aquelc contra quem se pede uma tutela jurisdicional, considerando terceiros todos

119. The concept of law, p. 18-19.

120. HART, ob. cit, p. 20.

121. Istituzioni di diritlo procesuale civilc, v. 2, p. 234. 
aqueles que não sejam sujeitos desse vínculo jurídico-material narrado, ainda que "participem também do processo" - por exemplo como partes acessórias. ${ }^{122}$ Misturando assim o conceito de terceiro com elementos do direito substantivo - ainda que abstratos, in statu assertionis , seus adeptos negam a condição de parte a sujeitos que. inegavelmente, figuram na relação processual, integrando o contraditório. Fica inexplicado, em decorrência, como esse sujeito é titular de todos (ou quase todos, no caso do assistente) os direitos, deveres, faculdades e ônus de uma parte, e mesmo assim é chamado "terceiro" Mais que isso, estando presente no feito, esse pseudo-terceiro também se submete à coisa julgada (ou à eficácia da intervenção), tal como uma verdadeira parte.

Afrrma-se que o conceito estipulado nesses moldes é útil para apontar a legitimidade e o interesse juridico do terceiro a intervir, pois aponta para o vínculo que o une à res in iudicium deducta. ${ }^{123}$ Ocorre, no entanto, que, a pretexto de referir um fenômeno processual, essa definição deixa a descoberto os muitos outros âmbitos do processo em que se lança mão do termo, ao considerar "terceiros" sujeitos que estão vinculados à imutabilidade do conteúdo decisório, são responsáveis pelo custo do processo, podem determinar a suspeição ou o impedimento do juiz, estão sujeitos aos efeitos da litispendência, e. de resto, ostentam todos os demais deveres, onus e faculdades processuais .. pessoas para as quais a lei confere inarredavelmente, em inúmeras oportunidades, a qualidade de parte. Ademais, justificar a busca do conceito de terceiro com base em sua legitimidade e interesse para intervir autorizaria fazer o mesmo com a definição de parte, restringindo-a à de parte legitima - o que seria evidente absurdo. Não é possível, portanto, construir uma definição de terceiro, que pretenda ser proficua ao processo civil, nos termos pretendidos por essa corrente doutrinária. Certo está Liebman, ao estender o conceito de parte a todos os "sujeitos do contraditório instituído perante o juiz" 124 independentemente da ligação que mantenha com a relação controvertida afirmada na inicial.

122. BaPtista DA SILva, Curso de processo civil, p. 235-241; GreCo FILho, Da intervenção de terceiros, p. 28-36; SCARPINELLA BUENO, Partes e terceiros no processo civil brasileiro, esp. p. 2-10.

123. SCARPInella Bueno, Partes e terceiros no processo civil brasileiro, p. 4; GRECOFilho, Da int'venção de terceiros, p. 28-29.

124. LIEBMAN, Manuale di diritto processuale civile. p. 89. 
Por tudo isso, tomando-se por base as premissas e os objetivos traçados no presente trabalho, a mais adequada definição de terceiro, em direito processual civil, é a aqui defendida, que designa como tal o sujeito que não é parte em determinado processo e, portanto, não pode ficar submetido à autoridade da coisa julgada ali formada.

São Paulo. dezembro de 2004.

\section{Bibliografia.}

ALLORIO, Enrico. La cosa giudicata rispetto ai terzi. Milano: Giuffiè, 1992.

ALVES, Alaôr Caffé. Apresentação. In: BOBBIO, Norberto. Teoria della norma giuridica, 1993, trad. port. de F P. Baptista e A. B. Sudatti, Teoria da norma juridica. São Paulo: Edipro, 2001.

ARAGÃO, Egas Dirceu Moniz de. Observações sobre os limites subjetivos da coisa julgada. Revista dos Tribunuis, $n$. 625/7.

ARFNHART, Sérgio Cruz. A efetivação de provimentos judiciais e a participação de terceiros. In: DIDIER JÚNIOR, Fredie; WAMBIER, Teresa Arruda Alvim (coords.). Aspectos polêmicos e atuais sobre os terceiros no processo civil. São Paulo: Revista dos Tribunais, 2004.

BEDAQUE, José Roberto dos Santos. Direito e processo -... influência do direito material sobre o processo. 2. ed. São Paulo: Malheiros, 2001.

BUENO, Cássio Scarpinella. Partes e terceiros no processo civil brasileiro. São Paulo: Saraiva, 2003.

BOBBIO, Norberto. Dalla strutura alla funzione, in Nuovi studi di teoria del diritto. Milano: Kdizioni di Comunità, 1977.

CALAMANDREI, Piero. Istituzioni di diritto processuale civile, 1943, trad. esp. de S. S. Melendo, Derecho procesal civil, v. 1. Buenos Aires: Ediciones Juridicas EuropaAmerica, 1973.

CALIXTO, Negi; MARINS, Victor A. A. Bonfim. Eficácia da sentença e coisa julgada perante terceiros. Revista dos Tribunais, n. 632/44.

CARNEIRO, Athos Gusmão. Intervenção de terceiros. 11. ed. São Paulo: Saraiva, 2000. 
CARNELUTTl, Francesco. Istituzioni del nuovo processo civile italiano, 1956, trad. port. de A. S. W. Batista. Instituições do processo civil, v. I, São Paulo: Classic Book, 2000.

Efficacia diretta e efficacia riflessa della cosa giudicata. in Studi di diritto processuale. Padova: Cedam, 1925.

Teoria generale del diritto, 1940, trad. port. de A. C. Ferreira, Teoria geral do direito. São Paulo: Lejus, 1999.

CHIOVENDA, Giuseppe. Istituzioni di diritto processuale civile. 2. ed., trad. port. de J. Menegale, Instituições de direito processual civil, 3. ed., v. I e 2, 1969.

CINTRA, Antonio Carlos de Araújo. Comentários ao código de processo civil. 2. ed. v. 4. Rio de Janeiro: Forense, 2003.

Estudo sobre a substituição processual no direito brasileiro. Revista dos Tribunais, n. 438/23.

COSTA, Moacyr Lôbo da. Assistência (processo civil brasileiro). São Paulo: Saraiva, 1968.

COUTURE, Eduardo Juan. Fundamentos del derecho procesal civil. 3. ed. Buenos Aires: Depalma, 1958.

DINAMARCO, Cândido Rangel. Coisa julgada e intervenção de terceiros. In: Intervenção de terceiros. São Paulo: Malheiros, 1997.

. Instituições de direito processual civil.v. 2 e 3. São Paulo: Malheiros, 2001. . Litisconsórcio. 7. ed. São Paulo: Malheiros, 2002.

- O princípio do contraditório e sua dupla destinação. In: Fundamentos do processo civil moderno. 5. ed. v. 1. São Paulo: Malheiros, 2002.

. Relativizar a coisa julgada material. In: Nova era do processo civil. São Paulo: Malheiros, 2003.

DINAMARCO, Pedro da Silva. Ação civil pública. São Paulo: Saraiva, 2001.

FARIA, José Eduardo (org.). Regulação, direito e democracia. São Paulo: Fundação Perseu Abramo, 2002.

FAZZALARI, Elio. The judgment and the authority of res judicata, in Italian yearbook of civil procedure. v. 1, Milano: Giuffrè, s. d..

FERRAZ JUNIOR, Tércio Sampaio. Introdução ao estudo do direito - decisão, técnica, dominação. 2. ed. São Paulo: Atlas. 1994. 
. Apresentação. In: LUHMANN, Niklas. Legitimation durch verfahren, 1969, trad. port. de M. C. Côrte-Real, Legitimação pelo procedimento. Brasília: Universidade de Brasilia, 1980.

- O pensamento jurídico de Norberto Bobbio. In: BOBBIO, Norberto. Teoria dell' ordinamento giuridico. 1982, trad. port de M. C. C. dos Santos, Teoria do ordenamento jurídico. 10. ed. Brasília: Lniversidade de Brasília, 1997.

GIDI, Antonio. C'oisa julgada e litispendência em ações coletivas. São Paulo: Saraiva, 1995.

GOLDSCHMIDT, James. Zivilprozessrecht, 1932, trad. port. de R. R. Gama, Direito processual civil. Curitiba: Juruá, 2003.

GOMES, Orlando. Obrigações. 15. ed. Rio de Janeiro: Forense, 2002.

GRECO FILHO, Vicente. Da intervenção de terceiros. 3. ed. São Paulo: Saraiva. 1991.

GRINOVER, Ada Pellegrini. [et al.]. Código brasileiro de defesa do consumidor comentado pelos autores do anteprojcto. 7. ed. Rio de Janeiro; Forense. 2001.

A coisa julgada perante a constituição. a lei da ação civil pública, o estatuto da criança e do adolescente e o código de defesa do consumidor. In: O processo em evolução. 2. Łd. Rio de Janciro: Forense Universitária, 1998.

. O novo processo do consumidor. In: O processo em evolução. 2 . ed. Rio de Janeiro: Forense Universitária, 1998.

HART, Herbert Lionel Adolphus. The concept of law, 1961, trad. port. de A. R. Mendes, O conceito de direito. 2. «d. Lisboa: Fundação Calouste Gulbenkian, 1994.

LENT, Friedrich. Zivilprozessrecht, 1959, trad. it. de E. Ricci, Diritto processuale civile tedesco. Napoli: Morano, 1962.

LIEBMAN, Enrico Tullio. Efficacia ed autorità della sentenza, 1962, trad. port de A. Buzaid. B. Aires e A. P. Grinover, Eficácia e autoridade da sentença. 3. ed. Rio de Janeiro: Forense, 1984.

- Manuale di diritto processuale civile. 1981, trad. port. de C. R. Dinamarco, Manual de direito processual civil. 2. ed., v. I. Rio de Janeiro; Forense, 1987.

. The notion of res judicata. In: Italian vearbook of civil procedure. v. 1, Milano: Giuffrè, s. d.

LOPES, José Reinaldo de Lima. As palavras e a lei: direito, ordem e justiça na história do pensamento juridico moderno. São Paulo: 34/Edesp, 2004.

LUMIA, Giuseppe. Lineamenti di teoria e ideologia del diritto. 1973. trad. port. de D. Agostinetti, Elementos de teoria e ideologia do direito. São Paulo: Martins Fontes, 2003. 
MACHADO, João Baptista. Introdução ao direito e ao discurso legitimador. Coimbra: Almedina, 2002.

MARCATO. Antonio Carlos [et. al.]. Código de processo civil interpretado. São Paulo: Atlas, 2004.

MARINS, Victor A. A. Bonfim e CALIXTO, Negi. Eficácia da sentença e coisa julgada perante terceiros. Revista dos Tribunais, n. 632/44.

MARQUES, José Frederico. Instituições de direito processual civil. 4. ed. v. 2. Rio de Janeiro: Forense, 1971.

1969.

Instituições de direito processual civil. 3. ed. v. 4. Rio de Janeiro: Forense,

MESQUITA, José Ignacio Botelho de. Coisa julgada. Rio de Janeiro: Forense, 2004.

MIRANDA, Francisco Cavalcanti Pontes de. Comentários ao código de processo civil. 3. ed., t. V. Rio de Janeiro: Forense, 1997.

MONTELEONE. Girolamo. I limitti soggettivi del giudicato civile. Padova: Cedam, 1978.

MOREIRA, José Carlos Barbosa. Eficácia da sentença e autoridade da coisa julgada. In: Temas de direito processual (terceira série). São Paulo: Saraiva, 1984.

NEVES, Celso. Coisa julgada civil. São Paulo: Revista dos Tribunais, 1971.

OLIVEIRA, Carlos Alberto Alvaro de. Ciarantia do contraditório. In: Garantias constitucionais do processo civil. São Paulo: Revista dos Tribunais, 1999.

ORESTANO, Riccardo. $L$ appello civile in diritto romano. 2. ed. Torino: G. Giappichelli, 1966.

PINTO, Teresa Celina de Arruda Alvim. O terceiro recorrente. Revista de Processo, $n$. $59 / 27$.

PORTO, Sérgio Gilberto. Comentários ao código de processo civil. v. 6. São Paulo; Revista dos Tribunais, 2000.

PISANI, Andrea Proto. Lezioni di diritto processuale civile. 2. ed. Napoli; Jovene. 1996.

REALE, Miguel. Lições preliminares de dircito. 23. ed. São Paulo: Saraiva, 1996.

ROCCO, Ugo. Trattato di diritto processuale civile. 2. ed. v. 2. Torino: UTET, 1966.

ROSENBERG, Leo. I.ehrhuch des deutschen zivilprozessrechts, 195I, trad. esp. de A.

R. Vera, Tratado de derecho procesul civil. t. I. Buenos Aires: EJEA, 1955. 
Lehrbuch des deutschen zivilprozessrechts. 1951, trad. esp. de A. R. Vera, Tratado de derecho procesal civil. t. II. Buenos Aires: EJEA, 1955.

SANTOS, Moacyr Amaral. Primeiras linhas de direito processual civil. 18. ed. São Paulo: Saraiva, 1997. v. 2

SILVA. Ovídio Baptista da. Curso de processo civil. 6. ed. São Paulo: Revista dos Tribunais, 2002.

SOSA, Angel Landoni. La cosa juzgada en los procesos colectivos. In: Yarshell, Flávio Luiz; Moraes, Maurício Zanoide de (Coords.). Estudos em homenagem à professora Ada Pellegrini Grinover. São Paulo: DPJ, 2005.

TALAMINI, Eduardo. Partes, terceiros e coisa julgada (os limites subjetivos da coisa julgada). In: DIDIER JÚNIOR, Fredie; WAMBIER, Teresa Arruda Alvim (Coords.). Aspectos polêmicos e atuais sobre os terceiros no processo civil. São Paulo: Ruvista dos Tribunais, 2004.

WACH. Adolf. Handbuch des deutschen zivilprozessrechts. t. I, 1885, trad. esp. de T. Banzhaf, Manual de derecho procesal civil.v. 2. Buenos Aires: EJEA. 1977.

WARAT, Luis Alberto. O direito e sua linguagem. 2. ed. Porto Alegre: Sergio Antonio Fabris, 1995.

WATANABE. Kazuo. Da cognição no processo civil. 2. ed. Campinas: Bookseller, 2000. 